\title{
PENINGKATAN KEMAMPUAN SISWA MENGGAMBAR EKSPRESIF MELALUI PENDEKATAN DIRECT EXPERIENCE BERBANTUAN MEDIA KOMPUTER
}

\section{IMPROVINGSTUDENTS'EXPRESSIVE DRAWING ABILITY THROUGH COMPUTER ASSISTED DIRECT EXPERIENCE APPROACH}

\author{
RUSMIYATI
}

SDN Pejaten Timur 22 Pagi

\begin{abstract}
Received: March 09, 2021

Computer-assisted learning in the era of digital technology supports accelerated efforts to Revised: September 30, 2021 improve expressive drawing process skills through the help of computer media. The purpose of Accepted: November 26, 2021 this study was to identify and describe students' learning to draw. Respondents consisted of 21 students of SON Pejaten Timur 22 South Jakarta in the SBDP subject of expressive drawing using computer media. The type of research conducted is Classroom Action Research (CAR) which consists of two cycles, the first cycle was carried out on October 3, 2019, and the second cycle on October 10, 2019 using the Kemmis and Me Taggart model which consisted of four components, namely: planning, action, observation, and reflection. Data collection techniques were carried out by direct observation and individual practice. This classroom action research uses qualitative and quantitative approach theory. The results showed that in the first cycle the lowest score was 34, while the highest score was 74. The number of students who had achieved the KKM score and categorized as complete were 14 out of 21 students or $66.67 \%$. In cycle II, the lowest student score was 64, while the highest score was 74. The number of students who had achieved the KKM score and was categorized as complete was $85.71 \%$, and explained that the use of a computer-assisted direct experience approach can improve students' skills in learning expressive drawing.
\end{abstract}

\begin{abstract}
Abstrak.
Pembelajaran berbantuan media komputer di era teknologi digital mendukung upaya percepatan untuk meningkatkan keterampilan proses menggambar ekspresif melalui bantuan media komputer. Tujuan penelitian ini adalah untuk mengetahui dan mendeskripsikan pembelajaran menggambar siswa. Responden terdiri dari 21 siswa SON Pejaten Timur 22 Jakarta Selatan pada mata pelajaran SBDP menggambar ekspresif dengan media komputer. Jenis penelitian yang dilakukan adalah Penelitian Tindakan Kelas (PTK) yang terdiri dari dua siklus, siklus I dilaksanakan pada tanggal 3 Oktober 2019, dan siklus II pada tanggal10 Oktober 2019 menggunakan model Kemmis dan McTaggart yang terdiri dari empat komponen, yaitu: perencanaan, tindakan, pengamatan, dan refleksi. Teknik pengumpulan data dilakukan dengan observasi dan praktek langsung secara individual. Penelitian tindakan kelas ini menggunakan teori pendekatan kualitatif dan kuantitatif. Hasil penelitian menunjukkan bahwa pada siklus I nilai terendah adalah 34, sedangkan nilai tertinggi adalah 74. Jumlah siswa yang telah mencapai nilai KKM dan dikategorikan tuntas adalah sebanyak 14 orang dari 21 siswa atau 66,67\%. Pada siklus II, nilai siswa terendah 64, sedangkan nilai tertinggi adalah 74. Jumlah siswa yang telah mencapai nilai KKM dan dikategorikan tuntas adalah 85,71\%, dan menjelaskan bahwa penggunaan pendekatan pengalaman langsung berbantuan komputer dapat meningkatkan keterampilan siswa dalam pembelajaran menggambar ekspresif.
\end{abstract}

Keywords: $\quad$ Direct experience strategy, expressive drawing, computer media

Kata kunci: $\quad$ Strategi pengalaman langsung, menggambar ekspresif, media komputer

$\left(^{\star}\right)$ Corresponding Author: rusmiyati.im@gmail.com

How to Cite: Rusmiyati, (2021). Peningkatan Kemampuan Siswa Menggambar Ekspresif Melalui Pendekatan Direct Experience Berbantuan Media Komputer. Jurnal Lingkar Mutu Pendidikan, 18 (2), 232-237. https://doi.org/10.54124/jlmp.v18i1.5

\section{PENDAHULUAN}

Seiring perkembangan dan kemajuan zaman berikut alat teknologi, sudah menjadi bagian dari kehidupan masyarakat dunia. Tak terkecuali di negeri Republik Indonesia, generasinya sudah sangat familiar dengan berbagai produk teknologi, khususnya untuk keperluan dalam bidang kependidikan. 
Salah satu alat yang sudah familiar dikenal adalah komputer. Komputer bukan lagi menjadi barang asing bagi siswa yang belajar di tingkat Sekolah Dasar (SD) dewasa ini. Aspek teknologi ini telah menjadi bagian yang tak dapat terpisahkan. Perkembangan teknologi yang pesat, mengharuskan guru sebagai pendidik dapat menyiapkan siswa agar mampu menghadapi masa depan mereka yang akan lebih didominasi oleh penggunaan komputer sebagai sarana teknologi informasi.

Masalah yang ditemui di kelas ISDN Pejaten Timur 22 Pagi untuk muatan pelajaran SBDP adalah pembelajaran yang berpusat pada guru yang hanya menugaskan peserta didik untuk menggambar ekspresif yang sering kita kenai menggambar bebas. Seharusnya, menggambar bebas dapat membuat anak menjadi kreatif dalam mencurahkan ide dan gagasan ke dalam gambarnya, namun jika tugas tersebut tanpa pengarahan atau strategi pembelajaran yang tepat tentu hal ini akan membuat anak menjadi kurang kreatif dan bingung akhirnya akan menggambar apa.

Proses pembelajaran yang dilakukan guru pun kurang menarik, selain itu sumber belajar hanya menggunakan buku saja tanpa penggunaan media pembelajaran berbantuan komputer ketika proses belajar mengajar. Hal ini mengakibatkan rendahnya hasil belajar serta minimnya daya serap materi serta kreatifitas siswa dalam menggambar ekspresif.

Sebenarnya, yang paling efektif adalah pembelajaran yang melibatkan secara langsung dengan pengalaman-pengalaman belajar yang dikombinasikan dengan penggunaan teknologi berupa media komputer. Sehingga dalam hal ini, peneliti mencoba untuk mencari cara meningkatkan hasil belajar SBDP dengan pendekatan (direct experience) atau pengalaman secara langsung dengan berbantuan media komputer. Hal ini diharapkan akan memudahkan siswa dalam menyerap pengetahuan dan keterampilan baru yang diberikan guru sehingga hasil belajar siswa dalam hal menggambar ekspresif pada muatan pelajaran SBDP dapat lebih ditingkatkan.

Terkait menggambar ekspresif, ada beberapa penelitian yang telah dilakukan. Diantaranya adalah yang telah dilakukan Fikhi Frasethian dari Universitas Pendidikan Indonesia Bandung, berjudul Penerapan Pendekatan Inspiratif Direct Experience Untuk Meningkatkan Kemampuan siswa dalam Menggambar Ekspresif: Penelitian Tindakan Kelas di SD Mathlaul Khaeriyah Kelas IV (Frasethian, 2013).

Penelitian ini melaporkan hasil dari penerapan pendekatan inspiratif direct experience yang dapat meningkatkan kemampuan menggambar ekspresif siswa dalam hal kejelasan ide, kesesuain tema, penguasaan media dan teknik, serta kreativitas. Dalam perumusan desain pembelajaran, diawali dengan pengalaman yang dimiliki oleh siswa. Proses pembelajaran yang dilakukan yaitu dengan mengingatkan siswa akan pengalaman yang dimiliki. Hasil penelitian menunjukkan bahwa kemampuan siswa mengalami peningkatan yang signifikan.

Demikian pula penelitian yang dilakukan oleh Agus Lias Tari dalam jurnal eprints Universitas Negeri Makassar yang berjudul Analisis terhadap Gambar Ekspresif Karya Murid Kelas I Sekolah Dasar Negeri 23 Kebunsari Kecamatan Wonomulyo Kabupaten Polewali Mandar Provinsi Sulawesi Barat. Penelitian tersebut bertujuan mendeskripsikan tentang karakteristik, media yang digunakan dan objek yang digambar pada gambar ekspresif karya siswa kelas I Sekolah Dasar. Observasi, wawancara, uji tindakan dan dokumentasi adalah teknik pengumpulan data yang dilakukan. Sedangkan teknik analisis data dengan cara analisis secara kuantitatif dan kualitatif pada gambar ekspresif yang diciptakan murid (Tari, 2013).

Alvin Toffler, seorang ilmuan dan futuristik terkemuka mengemukakan bahwa tiga gelombang penting dalam perkembangan peradaban manusia yaitu: teknologi pertanian; teknologi industri; dan teknologi elektronik (Pribadi2014). Eraperkembangan teknologi elektronik ini berlangsung pada masyarakat informasi yang ditandai dengan frekuensi pertukaran informasi yang tinggi dan berlangsung cepat. Masyarakat pada tahap ini menganggap informasi sebagai kekuatan (Power) yang menentukan banyak aspek kehidupan manusia.

Siapa yang menguasai informasi adalah yang akan menjadi pemenang. Untuk itu, pengenalan teknologi informasi perlu diperkenalkan kepada siswa sekolah dasar. Salah satu upaya yang perlu dilakukan untuk menggapai penguasaan teknologi di masa depan adalah melalui pengenalan teknologi informasi kepada siswa sekolah. Pada akhirnya gurudiharapkanakanmampumengenalkan siswa dengan teknologi. 
Komputer merupakan sarana teknologi informasi yang dapat membantu dan mendukung pelaksanaan tugas dan aktivitas pekerjaan serta membantu meningkatkan kinerja manusia. Komputer sebagai sebuah teknologi telah membantu manusia dalam melakukan sejumlah aktivitas kehidupan, seperti: pengolahan kata, pemprosesan data, desain dan pengembangan, komunikasi dan hiburan. Komputer juga digunakan sebagai sarana untuk mengkomunikasikan sebuah ilmu pengetahuan dan juga keterampilan (Pribadi 2014). Realita ini telah menjadikan teknologi komputer sebagai media yang popular sebagai sarana pembelajaran dan sekaligus hiburan. Berkembangnya teknologi komputer yang sangat pesat, mengharuskan kita sebagai pendidik dapat menyiapkan anak yang mempunyai bakat, rasa ingin tahu yang tinggi serta menyalurkannya melalui media komputer.

Menggambar sebagai salah satu bentuk seni bermanfaat sebagai alat untuk mengembangkan kemampuan berkomunikasi nonverbal dan berfungsi sebagai alat untuk mengungkapkan ide, perasaan dan emosi. Secara umum, menggambar adalah sebuah kegiatan untuk membentuk imajinasi, dengan menggunakan beberapa pilihan teknik dan alat.

Dalamduniapendidikananak, seni digunakan sebagai mediauntuk memenuhi fungsi perkembangan baik fisik, mental, maupun kecerdasan anak. Di mana anak yang memiliki kecerdasan ini cenderung menyukai apresiasi seni, diantaranya suka mencoret-coret dan menggambar.

Dalam buku yang berjudul Perkembangan dan Konsep Dasar Pengembangan Anak Usia Dini, dinyatakan bahwa seni adalah kesempatan dimana siswa dapat menggunakannya untuk mengkomunikasikan, dan menyampaikan ide-ide tentang dirinya, juga dunianya serta harapan untuk bekerja dengan cara mereka sendiri (Aisyah, 2014\}. Menggambar ekspresif bagi siswa merupakan salah satu jenis kegiatan bermain yang dilakukan dalam rangka memberikan kesenangan, kepuasan, ekspresi, eksplorasi dan unjuk kebolehan.

Saat ini, siswa telah mengenal komputer. Program menggambar dan mewarnai pada media komputer banyak digemari oleh siswa karena dapat mengekspresikan bakat seninya. Untuk itu, diharapkan menggambar dengan berbantuan media komputer dan dengan pendekatan pengalaman langsung (direct experience) akan dapat meningkatkan hasil belajarmenggambar ekspresif.

Dalam rangka mengembangkan kemampuan seni siswa sekolah dasar, salah satu aspek seni yang ditekankan dalam mengembangkan kemampuan seni adalah kemampuan siswa menggambar sederhana dengan pendekatan pengalaman secara langsung (direct experience). Direct experience merupakan sebuah stimulus daya cipta peserta didik yang mengkaitkan kepada pengalaman langsung.

Dalam penelitian ini pengalaman langsung berupa pengalaman yang telah dialami langsung oleh peserta didik baik secara klasikal atau individual yang bersifat rutin maupun insidental (Frasethian 2013\}.

Direct experience atau pengalaman langsung umumnya menunjukkan pengalaman yang diperoleh melalui persepsi indera langsung. Banyak sistem filosofis berpendapat bahwa pengetahuan atau keterampilan yang diperoleh melalui pengalaman langsung tidak dapat sepenuhnya diungkapkan dengan kata-kata (wikipedia n.d.).

Era perkembangan teknologi elektronik ini berlangsung pada masyarakat informasi yang di tandai dengan frekuensi pertukaran informasi yang tinggi dan berlangsung cepat. Masyarakat pada tahap ini menganggap informasi sebagai kekuatan "Power" yang menentukan banyak aspek kehidupan manusia. Siapa yang menguasai informasi adalah yang akan menjadi pemenang.

Untuk itu pengenalan teknologi informasi perlu di perkenankan kepada murid sekolah dasar kelas I. Salah satu upaya yang perlu dilakukan untuk menggapai penguasaan teknologi di masa depan adalah melalui pengenalan teknologi informasi kepada anak-anak sekolah dasar khususnya siswa kelas satu.

Berdasarkan pernyataan dan permasalahan tersebut di atas, peneliti berminat untuk mengadakan penelitian tentang Peningkatan Kemampuan Siswa Menggambar Ekspresi Melalui Pendekatan Direct Experience Berbantuan Media Komputer. Dari rumusan masalah penelitian tindakan kelas, penulis bertujuan untuk memahami penyusunan desain pembelajaran penerapan pendekatan direct exprerience (pengalaman langsung) untuk meningkatkan kemampuan menggambar ekspresif berbantuan media komputer pada peserta didik kelas I SON Pejaten Timur 22 Pagi. Mencoba menerapkan pendekatan direct experience (pengalaman langsung) untuk meningkatkan kemampuan menggambar ekspresif berbantuan mediakomputer pada siswa 


\section{METODE PENELITIAN}

Penelitian ini menggunakan metode kualitatif deskriptif dengan desain Penelitian Tindakan Kelas (PTK). Jenis penelitian yang dilakukan adalah penelitian tindakan kelas model Kemmis dan Mc Taggart, yang merupakan pengembangan dari konsep dasar yang diperkenalkan oleh Kurt Lewin yang terdiri dari empat komponen, yaitu: Perencanaan (Planning), Tindakan (Action), Pengamatan (Observation), Refleksi (Reflecting). Penelitian kualitatif merupakan penelitian yang berupaya membangun pandangan orang yang diteliti secara rinci serta dibentuk dengan katakata, gambaran holistik (menyeluruh dan mendalam) dan rumit (Tohirin 2013). Pendekatan kualitatif digunakan untuk melihat rancangan, pelaksanaan dan evaluasi pembelajaran. Sedangkan pendekatan kuantitatif untuk melihat kemampuan siswa setelah mengikuti pembelajaran. Desain dan prosedur tindakan yang dilaksanakan mengacu kepada tahap penelitian yang terdiri dari perencanaan, pelaksanaan dan pengamatan serta refleksi.

Partisipan penelitian ini berjumlah 21 siswa SDN Pejaten Timur 22 Pagi Kecamatan Pasar Minggu, Jakarta Selatan terdiri dari anak 12 laki laki dan 9 anak perempuan mata pelajaran SBDP (Seni Budaya dan Prakarya) menggambar ekspresif dengan media berbantuan komputer. Penelitian dilakukan pada bulan September dan Oktober tahun 2019, di semester ganjil tahun pelajaran 2019/2020.

Teknik pengumpulan data pada evaluasi pembelajaran dilakukan berdasarkan hasil penelitian guru. Ada dua teknik yang dilakukan untuk mengevaluasi perkembangan siswa, yaitu observasi dan praktek langsung secara individual. Observasi yaitu pengamatan dan pencatatan secara sistematis terhadap unsurunsur yang nampak dalam suatu gejala pada objek penelitian (Widoyoko 2014). Sedangkan evaluasi praktek langsung yaitu melihat keterampilan anak dalam menggambar melalui bantuan komputer, atau kemampuan anak dalam mengikuti kegiatan. Penilaian diambil dari data tentang peningkatan seni menggambar melalui pembelajaran berbantuan komputer di Sekolah Dasar yang meliputi deskripsi umum, metode, media, dan evaluasi pembelajaran menggambar dengan media komputer.

Teknik analisis data dalam penelitian ini menggunakan teknik analisis deskriptif kualitatif-kuantitatif. Analisis data secara kualitatif digunakan untuk menganalisis data kualitatif, seperti hasil observasi. Untuk menganalisa data kuantitatif seperti hasil tes, digunakan analisis data deskriptif kuantitatif. Data kuantitatif berupa nilai hasil belajar siswa yang didapat dengan menggunakan teknik analisis statistik deskriptif misalnya, mencari nilai rata-rata. Tolak ukur keberhasilan dalam penelitian ini adalah jika hasil tes siswa selama siklus I mengalami perbaikan dan hasil tes siklus II menunjukkan peningkatan dibandingkan dengan hasil tes siklus I.

Tes tertulis sebagai evaluasi pembelajaran dilakukan untuk menganalisis tingkat keberhasilan atau prosentase keberhasilan setelah proses belajar mengajar pada setiap siklusnya. Analisis ini dihitung dengan menggunakan statistik sederhana, yaitu dengan menghitung rata rata, menjumlahkan seluruh nilai yang diperoleh siswa yang ada di kelas yang dijadikan sample kemudian dibagi degan jumlah siswa yang ada di kelas sample.

\section{HASIL DAN PEMBAHASAN}

Penelitian ini akan meyajikan hasil penelitian tentang penggunaan media komputer dalam meningkatkan kemampuan siswa menggambar ekspresif melalui pendekatan direct experience. Adapun hasil lengkap penelitian ini dapat disajikan secara runtut sebagai berikut:

Hasil Pratindakan, dijelaskan bahwa hasil observasi dan evaluasi yang dilakukan guru terhadap kegiatan pembelajaran seni menggambar dengan mengenalkan perangkat komputer, ditujukan untuk mengetahui daya serap siswa, yaitu dengan melihat pencapaian nilai tertinggi, nilai terendah, nilai ratarata, serta melihat jumlah siswa yang berhasil mencapai nilai KKM. Skor Hasil Penilaian pada tahap pra siklus; KKM 70, jumlah siswa yang tuntas 8 siswa, rata-rata kelas 66.19, presentase (\%) ketuntasan $38.09 \%$.

Siklus 1, setelah melakukan proses mulai dari perencanan tindakan, pelaksanaan, observasi, dan refleksi atau evaluasi. Hasil pembelajaran Siklus I, disajikan tentang pengenalan perangkat komputer yang menunjukkan bahwa nilai rata-rata kelas adalah 73,14. Nilai tertinggi siswa adalah 84 dan nilai terendah siswa adalah 60. Siswa yang sudah mencapai nilai KKM dan dikategorikan sudah tuntas sebanyak 15 orang atau $71,42 \%$ dari 21 siswa di kelas I, sedangkan jumlah siswa yang belum mencapai 
nilai KKM dan dikategorikan belum tuntas yaitu 6 siswa atau sebesar 28,58\%. Dapat disimpulkan bahwa kegiatan pembelajaran pada siklus I dengan menggunakan metode tanyajawab dan demonstrasi menunjukkan adanya peningkatan yang cukup berarti, walau hasil belajar yang dicapai masih belum $75 \%$ tuntas.

Siklus 2, skor/nilai tes yang dilakukan pada akhir kegiatan pembelajaran merupakan hasil belajar yang diperoleh siswa dalam mengunakan komputer dalam menggambar ekspresif. Hasil belajar ini berupa nilai tes formatif yang terdiri dari sepuluh soal pilihan ganda. Hasil tes formatif 2 dengan materi menggambar dan mewarnai benda dua dimensi dan tiga dimensi.

Untuk materi menggambar dan mewarnai dua dimensi perolehan rata-rata kelas 78,66 , nilai terendah 64 dan nilai tertinggi adalah 90. Sedangkan untuk materi menggambar dan mewarnai tiga dimensi, nilai rata-rata kelas adalah 74,95, nilai terendah 62 dan nilai tertinggi adalah 86. Sehingga, jumlah siswa yang sudah mencapai kriteria ketuntasan minimal (KKM) dan dikategorikan sudah tuntas sebanyak 18 siswa atau 85,71\% dan jumlah siswa yang belum mencapai kriteria ketuntasan minimal (KKM) dan dikategorikan belum tuntas yaitu 3 siswa atau sebesar 14,29\% dari jumlah seluruh siswa kelas I.m

Sedangkan pada materi gambar tiga dimensi, jumlah siswa yang sudah mencapai KKM dan dikategorikan sudah tuntas sebanyak 16 siswa atau 76,19\% dari 21 siswa di kelas I, dan jumlah siswa yang belum mencapai kriteria ketuntasan minimal (KKM) dan dikategorikan belum tuntas yaitu 5 siswa atau sebesar 23,81\% dari jumlah seluruh siswa kelas I. Untuk materi gambar dua dimensi sebanyak 18 dari 21 siswa termasuk kategori tuntas dengan nilai 70 rentang nilai $70-$ 100, dan sebanyak 3 siswa dikategorikan tidak tuntas atau belum mencapai KKM dengan rentang nilai 0-69. Sedangkan untuk materi gambar tiga dimensi terdapat 16 siswa dari 21 siswa yang termasuk kategori tuntas dengan nilai 70 rentang nilai 70-100, dan sebanyak 5 siswa dikategorikan tidak tuntas atau belum mencapai kriteria ketuntasan minimal (KKM) dengan rentang nilai 0-69. Sehingga dapat disimpulkan bahwa kegiatan pembelajaran pada siklus II dengan menggunakan metode tanyajawab dan demonstrasi serta ditambahkan dengan metode eksperimen menunjukkan peningkatan cukup berarti, walau hasil belajar yang dicapai masih belum tuntas 100\%.

Tabel 1. Persentase Skor Hasil yang Dicapai

\begin{tabular}{|c|c|c|c|c|}
\hline & \multicolumn{4}{|c|}{ Hasil Yan9 Dica ai } \\
\hline & $\begin{array}{c}\text { Pra } \\
\text { Siklus }\end{array}$ & Siklus 1 & $\begin{array}{l}\text { Siklus } 2 \\
2 \mathrm{DI}\end{array}$ & $\begin{array}{c}\text { Siklus 2 } \\
\text { 3DI }\end{array}$ \\
\hline Nilai Terendah & 60 & 60 & 64 & 62 \\
\hline Nilai Tertinggi & 78 & 84 & 90 & 90 \\
\hline Nilai rata-rata & 66.19 & 73.14 & 78.66 & 74.95 \\
\hline \% Siswa yang tidak tuntas & $61.91 \%$ & $28.58 \%$ & $14.29 \%$ & $23.81 \%$ \\
\hline \% Siswayang tuntas & $38.09 \%$ & $71.42 \%$ & $85.71 \%$ & $76.19 \%$ \\
\hline
\end{tabular}

Hasil penelitian tindakan kelas yang dilaksanakan pada siklus I dan siklus II menjelaskan bahwa pembelajaran SBDP menggunakan media komputer dapat meningkatkan keterampilan siswa dalam menggambar dan mewarnai di kelas ISDN Pejaten Timur 22 Pagi.

Tabel 2. Rekap Hasil Belajar SBDP Pada Setiap Siklus

\begin{tabular}{cccc}
\hline No. & Siklus & Jumlah Siswa Tuntas Belajar & Presentase Ketuntasan \\
\hline 1. & Prasiklus & 8 & $38,09 \%$ \\
2. & Siklus I & 15 & $71,42 \%$ \\
3. & Siklus II (20) & 18 & $85,71 \%$ \\
& Siklus II (3DI & 16 & $76.19 \%$ \\
\hline
\end{tabular}

Capaian peserta didik mulai dari prasiklus, siklus I, dan siklus II dan dukungan hasil observasi selama pembelajaran SBDP, secara umum menunjukkan peningkatan yang signifikan. Oleh sebab itu, dapat dikatakan bahwa penelitian tindakan kelas dengan menggunakan media komputer ini telah berhasil meningkatkan hasil belajar siswa pada pelajaran SBDP materi menggambar dan mewarnai, mulai dari prasiklus, siklus I, dan siklus II yang dilaksanakan pada pembelajaran SBDP kelas I tentang menggambar ekspresif melalui pendekatan direct experience berbantuan media komputer, diperoleh hasil belajar siswa meningkat secara signifikan 


\section{SIMPULAN DAN SARAN}

Simpulan dari hasil penelitian bahwa pembelajaran dan pengajaran berbantuan media komputer menggunakan pendekatan direct experience dapat meningkatkan kemampuan menggambar ekspresif secara signifikan dengan tingkat keberhasilan yang baik. Pembelajaran dengan berbantuan media komputer, ditambah dengan pendekatan pengalaman secara langsung (direct experience) terbukti dapat meningkatkan hasil belajar afektif siswa, yang secara signifikan terlihat pada perhatian, minat, dan motivasi siswa.

Dengan pengalaman belajar yang secara langsung (direct experience) dirasakan siswa menjadi lebih aktif dan kreatif dalam proses pembelajaran, hal ini ditunjukkan dengan sering menjawab dan mengajukan pertanyaan kepada guru. Terjadi interaksi timbal balik yang baik antara guru dengan siswa. Adanya peningkatan kerjasama antar siswa dalam memecahkan masalah. Peningkatan hasil belajar psikomotor, siswa menjadi lebih berani untuk mengangkat tangan dan mengajukan pertanyaan. Siswa bersedia maju ke depan untuk menjawab pertanyaan dari guru dan menjadi lebih terampil dalam menggunakan media komputer.

Melalui penelitian ini diharapkan dapat memberi manfaat baik secara teoritis maupun secara praktis tidak hanya bagi guru dan siswa, melainkan juga sekolah. Manfaat bagi guru adalah memperbaiki proses pembelajaran di kelasnya serta mengetahui keefektifan mengajar dengan menggunakan media berbantuan komputer, bagi siswa sebagai upaya meningkatan keterampilan siswa dalam menggambar ekspresif dengan pengalaman secara langsung (direct experience). Sehingga akan berdampak pada hasil belajar siswa khususnya mata pelajaran SBDP dan bagi sekolah bermanfaat sebagai upaya meningkatkan mutu pendidikan khususnya mata pelajaran Seni Budaya dan Prakarya serta meningkatkan kemampuan kreatifitas menggambar ekspresif siswa dengan media komputer di sekolah.

\section{PUSTAKA ACUAN}

A, Pribadi Benny. Komputer Do/am Kegiatan Pengembangan Anak Usia Dini. Jakarta: Universitas Terbuka, 2014. Aisyah. Perkembangan dan Konsep Dasar Pengembangan Anak Usia Dini. Jakarta: Universitas Terbuka, 2014.

Frasethian, Fikhi. "Penerapan Pendekatan Inspiratif Direct Experience Untuk Meningkatkan Kemampuan Peserta Didik Dalam Menggambar Ekspresif: Penelitian Tindakan Kelas Di SO Mathlaul Khaeriyah Kelas IV." UP/ Repository, 2013.

Pribadi, Benny. Komputer Do/am Kegiatan Pengembangan Anak Usia Dini. Jakarta: Universitas Terbuka, 2014.

Komputer Dalam Kegiatan Pengembangan Anak Usia Dini. Jakarta: Universitas Terbuka, 2014.

Komputer Do/am Kegiatan Pengembangan Anak Usia Dini. Jakarta: Universitas Terbuka, 2014.

Tari, Agus Lias."Analisis terhadap Gambar Ekspresif Karya Murid Kelas ISekolah Dasar Negeri 023 Kebunsari Kecamatan

Wonomulyo Kabupaten Polewali Mandar Provinsi Sulawesi Barat." eprints Universitas Negeri Makassar, 2013.

Tohirin. Metode Penelitian Kualitatif do/am Pendidikan dan Bimbingan Konseling. Jakarta: PT Raja Grafindo Persada, 2013.

Widoyoko, Eko Putro. Teknik Penyusunan Instrumen Penelitian. Yogyakarta Pustaka Pelajar, 2014.

-.Teknik Penyusunan Instrumen Penelitian. Yogyakarta: Pustaka Pelajar, 2014.

wikiped ia. en.wikipedia.org. n.d. https:/len.wikipedia.org/wiki/Direct_experience (accessed Agustus 3, 2021). 